Review

\title{
Synergistic microbial interactions between lactic acid bacteria and yeasts during production of Nigerian indigenous fermented foods and beverages
}

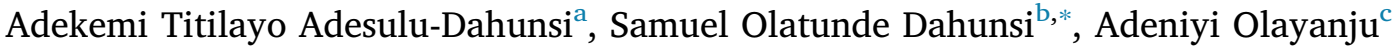 \\ ${ }^{a}$ Department of Microbiology, College of Pure and Applied Sciences, Landmark University, Omu-Aran, Kwara State, Nigeria \\ ${ }^{\mathrm{b}}$ Sustainable Management of Natural Resources and Environment Research Group, Faculty of Environment and Labour Safety, Ton Duc Thang University, Ho Chi Minh \\ City, Viet Nam \\ ${ }^{\mathrm{c}}$ Department of Agriculture and Biosystems Engineering, College of Engineering, Landmark University, Omu-Aran, Kwara State, Nigeria
}

\section{A R T I C L E I N F O}

\section{Keywords:}

Africa

Fermentation

Lactic acid bacteria

Synergistic

Yeast

\begin{abstract}
A B S T R A C T
Fermented foods and beverages are mainly consumed by the indigenous people of Africa and other developing countries. Traditional fermentation is an age-long means of preserving perishable foods especially when other methods of preservation are not available and/or not consistent. The main beneficial microorganisms that are responsible for the fermentation of African indigenous fermented foods and beverages are lactic acid bacteria and yeasts which may be present as microflora on the substrates or added as starter cultures. The understanding of the synergistic interaction between these microorganisms in the fermented food matrices result in improved nutrient availability, food quality, palatability, organoleptic properties, increased shelf life, safety, digestibility and also play beneficial roles in modulating host immune system thereby minimizing the risk of certain diseases.
\end{abstract}

\section{Introduction}

Fermentation is an ancient method of food processing and preservation (Hussain, 2018, chap. 11). It is a cheap means of preserving the quality and the organoleptic properties of the food especially when other methods of preservation are not available or consistent. Fermentation delivers to food desirable properties (i.e increased nutritional value, palatability) and extended shelf life (improved microbial stability and safety of the fermented foods for several days, months and up to years). This method of food production and preservation is of economic importance and is commonly practiced among the underdeveloped and developing countries of Africa as this has meet the challenges of food security in many region of Africa and are also affordable to the poor sector of the community, which directly addresses the problem of malnutrition, thereby leading to increased socioeconomy level (Adesulu \& Awojobi, 2014).

Fermented foods and beverages (FFB) are mainly consumed by the native people of Africa and other developing nations. Fermentation processes involved a complex microbiological interaction between different types of microorganisms (Sieuwerts, de Bok, Hugenholtz, \& van Hylckama Vlieg, 2008). The main beneficial microorganisms that are responsible for the fermentation of indigenous foods are lactic acid bacteria (LAB) and yeasts which may be present as microflora on the raw materials/substrates or added as starter (Adesulu \& Awojobi, 2014;
De Vuyst, Harth, Van Kerrebroeck, \& Leroy, 2016). The fermentation of cereal grains and cassava tubers to produce foods and beverages is indigenous to many countries in Africa.

Microorganisms in natural or controlled fermentation co-exist and interact with each other to produce quality end products. During the production of the traditional $\mathrm{FFB}$, there is need to understand the consortium of the natural micro-biota at every stages of fermentation, this is important to the quality of fermented food produced as each microorganism performed specific role(s), also the type of interaction that exist between the predominant microorganisms (especially LAB and yeast) present in the food matrices are important to the food quality (Vieira-Dalodé et al., 2006; Olanbiwoninu \& Odunfa, 2018). The occurrence of undesirable or pathogenic microorganisms during traditional fermentation may give product of inconsistent quality, therefore proper understanding of the activities and kinetics of the LAB and yeasts involved during fermentation processes is necessary in other to be able to identify and select strains with desirable functional characteristic which will guarantee quality and safety the fermented food products (Adesulu-Dahunsi, Jeyaram, \& Sanni, 2018a; AdesuluDahunsi, Sanni, Jeyaram, \& Banwo, 2017; Oguntoyinbo \& Narbad, 2015).

The understanding of the synergistic interaction/effect between these microorganisms during fermentation results in the improvement of nutrient availability in foods, and also improves the palatability,

\footnotetext{
* Corresponding author.

E-mail address: dahunsi.olatunde.samuel@tdtu.edu.vn (S.O. Dahunsi).
} 

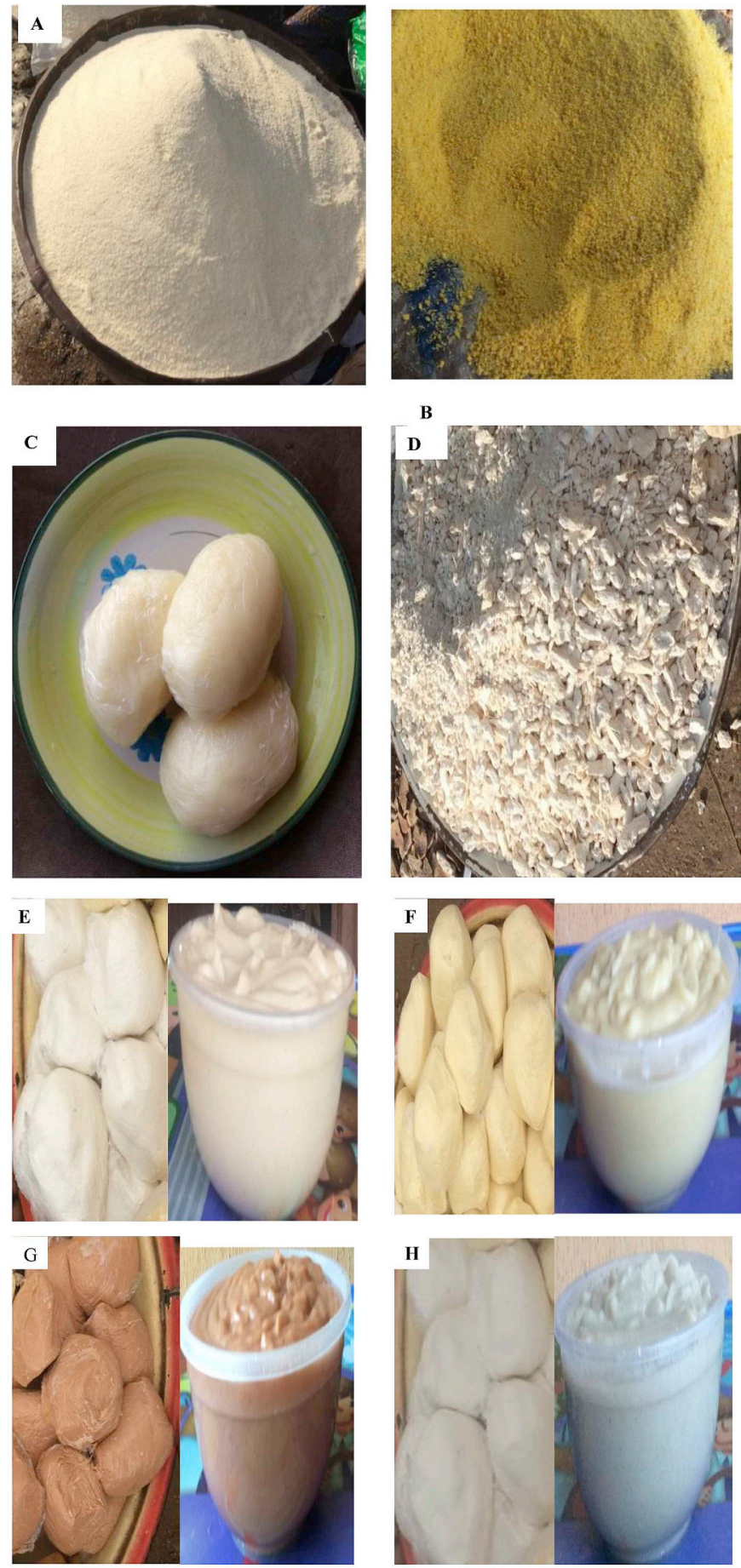

Fig. 1. Nigerian indigenous fermented foods and beverages. (A) White gari (B) Yellow (C) Fufu (D) Lafun (E) Ogi funfun (F) Ogi pupa (G) Ogi baba (H) Ogi jero (I) Eko (J) Iru (K) Ogiri (L) Owoh (M) Okpehe (N) Burukutu (O) Pito (P) Emu (Q) Kunun-zaki (R) Masa (S) Kokoro (T) Wara (U) Fried wara. (For interpretation of the references to color in this figure legend, the reader is referred to the Web version of this article.)

organoleptic properties, increasing food shelf life, and digestibility. The synergistic microbial relationship that co-exists between $\mathrm{LAB}$ and yeast species during production of African FFB with emphasis on Nigerian indigenous fermented foods (IFF) are reviewed.

\section{Nigerian indigenous fermented foods and beverages}

In Nigeria and other nations in Sub-Saharan Africa, IFF formed main dietary component of the citizenry, with some being used as infants weaning food, meals among adults or as refreshments. These foods play immense benefits on the health, nutrition and socio-economy status of the people (Adesulu \& Awojobi, 2014). In Nigeria, several traditional FFB are produced at the household level, they include, fermented cassava tubers (gari, fufu, lafun, abacha), fermented cereals (ogi, eko), fermented condiments (iru, ogiri, owoh, okpehe), fermented dairy products (nunu, wara), alcoholic and non-alcoholic beverages (emu, pito, dolo, burukutu, kunun-zaki, agadagidi) and snacks (masa, kokoro). In the course of production of these foods, LAB and yeasts are predominantly involved during the fermentation processes. Examples of these fermented foods are presented in Fig. 1.

\subsection{Fermented cassava tubers}

i. Gari: Gari is popularly consumed among the population of Central and West Africa. It is produced by solid state fermentation of the cassava tubers. In Nigeria, gari is consumed either by soaking in cold water (eaten with sugar or roasted groundnuts) or as a solid (referred to as $e b a$ ) made with hot water and taken with soup. It is a coarse flour with slightly sour taste and having white (white gari) or yellow (yellow gari) color (palm oil is added during processing of the yellow gari. Yellow gari is popularly called gari-yibo.

ii. Fufu: Fufu is a fermented food produced from cassava tubers. It is indigenous to people in the South-Eastern and South-Western part of Nigeria and is produced by submerged fermentation. The fermented slurry is cooked to form a thick paste and is usually eaten with soup. It is popularly called $a k p u$ by the South-Easterners.

iii. Lafun: Lafun also known as elubo lafun is widely consumed by the Yoruba's (South-West Nigeria). It is prepared by submerged fermentation, after fermentation and sun drying, it is milled into fine powdery form inform of flour. The flour is made into dough by adding it into boiling water and stirring, lafun is eaten with indigenous soup (gbegiri and ewedu soup).

iv. Abacha: Abacha is a popular snack food that is produced from cassava tuber. It is common among the people of South-Eastern Nigeria. Abacha is consumed with coconut or palm kernel/ground nuts

\subsection{Fermented cereals}

i. Ogi: Ogi is a mild acidic viscous gruel that is either produced from white maize variety (ogi funfun), yellow maize variety (ogi pupa), red sorghum variety (ogi baba) or millet (ogi jero). It is used as weaning foods and can also serves as breakfast beverages among adults. Ogi can be eaten with bean cake, sugar or milk. In Nigeria ogi as it is popularly called, is also known as akamu, or koko by the indigenous people.

ii. Eko: Eko (also known as agidi) is a cereal-based fermented food 
produced from fermented maize (white and yellow varieties). The production process is similar to that of ogi, but the difference is in the cooking process, the fermented ogi cake is cooked for a longer period to gelatinized and form a smooth paste. It is wrapped in banana leaves and allowed to cool. It is usually consumed with
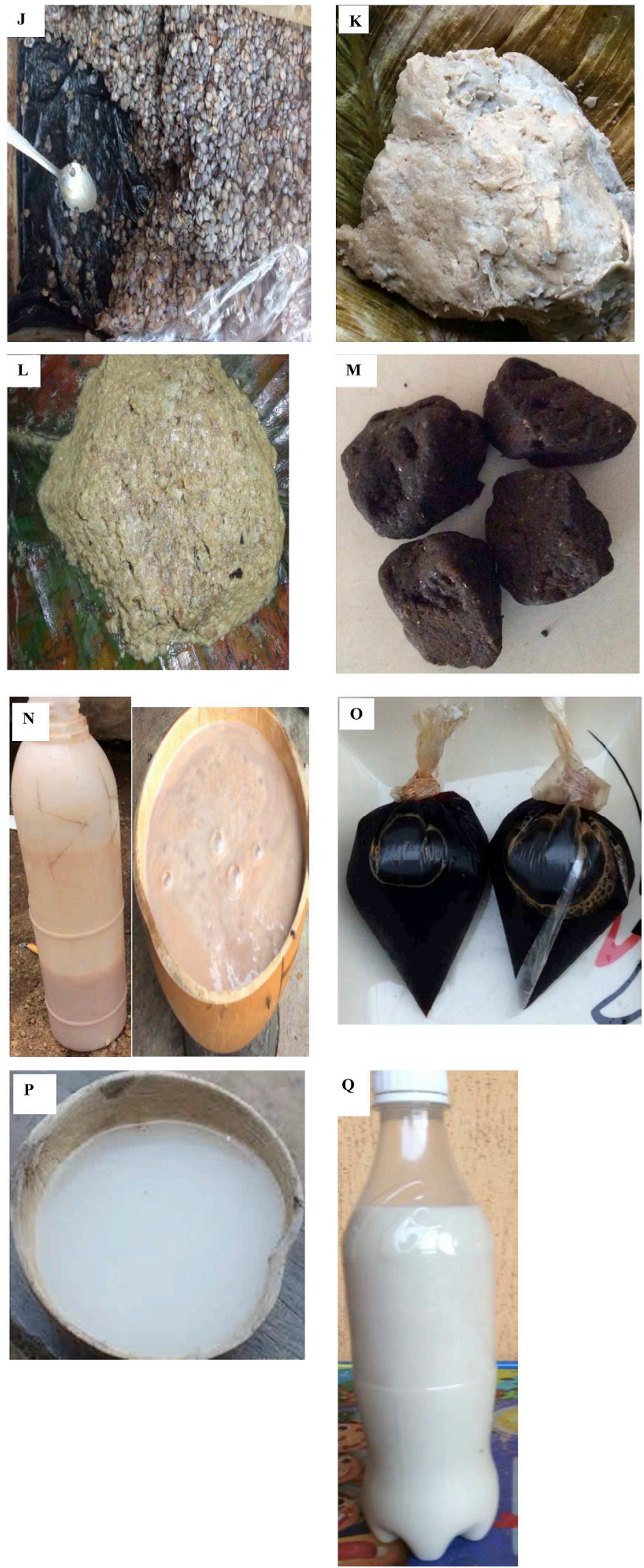

Fig. 1. (continued)
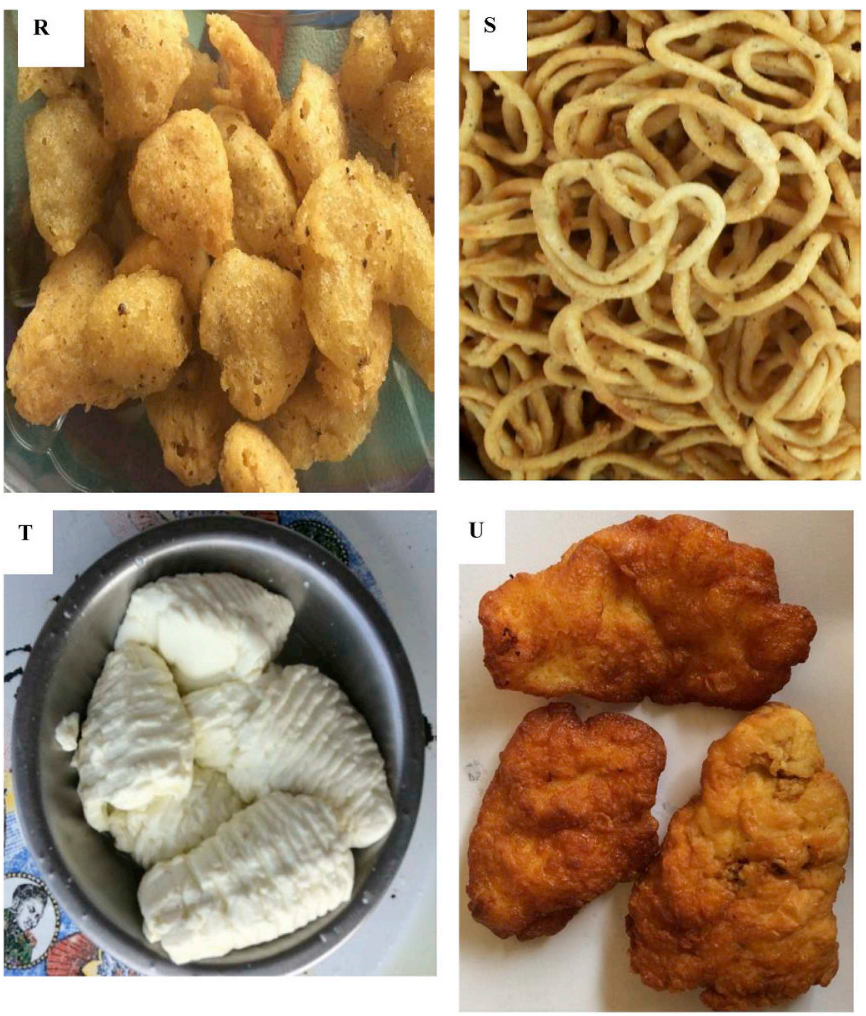

Fig. 1. (continued)

different indigenous stew and soup.

\subsection{Fermented condiments}

i. Iru: Iru (also called dawadawa) is a fermented condiment that is made from African locust beans (Parkia biglobosa). This condiment is rich in proteins, it is cheap and easily available in the markets. Because of the appealing aroma and taste when added to sauces and soups during cooking, it is sometimes used as a substitute for meat or fish by many low income earners or poor families. It is popularly hawked by the middle aged and elderly women in Nigerian markets in a calabash or wooden box. Many bacteria have been reportedly isolated from iru especially Bacillus sp. (Adewumi, Oguntoyinbo, Romi, Singh, \& Jeyaram, 2014). Iru is of two different types; iru woro and iru pete.

ii. Ogiri: Ogiri is produced from fermented melon seeds (Cucumeropsis mannii) or castor bean seed (Ricinus communis). It is not as popular as iru but is also consumed by the indigenous people. It is usually with unpleasant odour after fermentation, but when added to soup gives an appealing taste.

iii. Owoh: Owoh is a condiment that is produced by solid state fermentation of cotton seed (Gossypium hirsutum).

iv. Okpehe: Okpehe is produced from leguminous oil seeds (Prosopis africana). It is popular in the South Eastern part of Nigeria.

v. Ugba: Ugba is an indigenous condiment that is popular in the Eastern part of Nigeria. It is prepared by solid state fermentation of African oil beans seed (Pentaclethra macrophylla), containing up to 44\% protein content (Okechukwu, Ewelike, Ukaoma, Emejulu, \& Azuwike, 2012).

\subsection{Fermented dairy products}

i. Nunu: Nunu (popularly called fura de nunu) is an appetizing and refreshing fermented beverage from cow milk that is consumed with fura (millet flour compressed to balls) and granulated sugar. It has a 
sharp acid taste and is widely consumed in the Northern part of Nigeria. The milking process is done between the third and sixth months of lactating cows and it involves inoculating the fresh milk with a starter and allowing fermentation to take place for $24 \mathrm{~h}$ at room temperature. $\mathrm{LAB}$ and yeast are mainly isolated during nunu fermentation and each microorganism implicated gives characteristic flavor and taste.

ii. Wara: Wara is a traditional fresh milk product (curd) which may be eaten raw or fried in oil. Fried wara is used as meat and fish substitute by many indigenous people. It is hawked within walking distance of the Fulani's settlement, especially in the Northern part of Nigeria.

\subsection{Alcoholic and non-alcoholic beverages}

i. Emu: Emu (palm wine) is mildly alcoholic beverage that is made from palm sap. It is whitish in color and the fermentation process is dominated by Saccharomyces cerevisiae. It is popularly consumed in Nigeria and in some part of the West African countries. Emu is served during traditional marriage ceremonies or village meetings.

ii. Pito: Pito is an alcoholic traditional beverage produced from maize and sorghum grains. It is dark brown liquid drink and is popularly hawked and sold inside nylon by middle-aged women in many Nigerian markets.

iii. Burukutu: Burukutu is a fermented alcoholic beverage produced from sorghum grain with the alcohol content of about $4 \%(\mathrm{v} / \mathrm{v})$ (Sanni, 1993). It is a light brown viscous liquid beer that is popularly sold in Mammi markets (market attached to Nigerian soldier barracks) and some part of the Northern Nigeria.

iv. Kunun-zaki: Kunun-zaki is produced from millet grains, blended with spices and water. It is non-alcoholic fermented beverage that is widely consumed in Nigeria at anytime of the day by all age groups.

v. Agadagidi: Agadagidi is alcoholic beverage produced from the fermentation of ripe plantains. S. cerevisiae has been reported to be involved in the fermentation (Sanni \& Lonner, 1993). This indigenous beverage is popular in the South-Western part of Nigeria.

vi. Sekete: Sekete is an alcoholic beverage that is produced from fermented maize grains. Sekete beer is popularly consumed by the indigenous people in the rural communities of Western part of Nigeria (Sanni, 1988).

\subsection{Fermented snacks}

i. Masa: Masa (also known as waina) is a traditional fermented snack eaten with granulated sugar. It is produced from maize (Zea mays) or rice (Oryza sativa) and is popularly consumed in the Northern and Western part of Nigeria especially by the Muslims after Friday Jumat prayers (Sanni \& Adesulu, 2013).

ii. Kokoro: Kokoro is a light brownish fermented snack that is produced from maize grain. It is popularly sold and consumed in South Western Nigeria.

\section{Food and beverage fermentation by LAB and yeasts}

$\mathrm{LAB}$ and yeasts have been reported as frequent groups of microorganisms involved during fermentation of Nigerian traditional FFB (Adesulu-Dahunsi, Sanni, \& Jeyaram, 2017; Banwo, Sanni, Tan, \& Tian, 2012). The most important bacteria during the fermentation process are the Lactobacillaceae; they produce lactic acid from carbohydrates (Amoa-Awua, Appoh, \& Jakobsen, 1996; Kostinek et al., 2005). S. cerevisiae has also been reported as beneficial yeast in desirable food fermentation, it is an economically important microorganism that is commonly isolated during the fermentation processes. Yeasts are widely distributed in nature, they produce enzymes that are useful in food and chemical industries, and are also involved in the production of wine, sour dough bread and beer (Ogunsakin et al., 2017; Sanni \&
Lonner, 1993).

Lactobacillus sp., Pediococcus sp., Streptococcus sp., Leuconostoc mesenteroides, and Weissella sp. are dominant LAB species in the production of traditional FFB (Oyewole, 1997). Some yeast species including; S. cerevisiae, Geotrichum candidum, Clavispora lusitaniae, Rhodotorula sp., Cephalosporium sp., Fusarium sp., Debaryomyces hansenii, P. camemberti, P. roqueforti, C. mycoderma, C. parapsilosis, Candida krusei, C. tropicalis, Galactomyces, C. parapsilosis, Galactomyces geotrichum, Pichia kudriavzevii have also been isolated from these foods and $S$. cerevisiae are reported to be frequently involved in the fermentation of these foods (De Vuyst et al., 2016; Jespersen, 2003). Franz et al. (2014) reported that the most common LAB associated with traditional African FFB belongs to the genera Lactobacilli and Pediococci, with the predominance of L. plantarum and L. fermentum strains. Many African FFB have been investigated and the microflora responsible for the fermentation of these foods are mainly Lactobacillus, Pediococcus, Leuconostoc, Weissella and Saccharomyces species (Adesulu-Dahunsi, Sanni, \& Jeyaram, 2017; Nwachukwu, Achi, \& Ijeoma, 2010; Oguntoyinbo, Tourlomousis, Gasson, \& Narbad, 2011).

Recently, LAB and yeasts were isolated from gluten free sourdough preparation from Nigerian sorghum flour, the LAB isolated includes; Pediococcus and Weissella species, while the dominant yeast species is $S$. cerevisiae (Ogunsakin et al., 2017). Adesulu-Dahunsi, Sanni, and Jeyaram (2017) identified LAB (L. plantarum, P. pentosaceus and Weissella sp.) as the predominant microorganisms during fermentation of Nigerian indigenous fermented foods (gari, fufu, and ogi). Yeasts have been reported to play essential roles in flavor improvement and acceptability of fermented cereal gruels (Jespersen, 2003). Mixed cultures of $S$. cerevisiae and $L$. brevis inoculated during controlled fermentation of cereals for the production ogi gives a product with appealing aroma (Teniola \& Odunfa, 2001). Okagbue and Bankole (1992) and Odunfa and Oyewole (1997) reported the occurrence and dominance of $S$. cerevisiae during fermentation of traditional beverages. Padonou et al. (2009) also investigated the microbiology of fermented cassava for production of lafun and reported that L. fermentum, L. plantarum and W. confusa were LAB species isolated during the fermentation process, Kluyveromyces marxianus, Pichia scutulata, and Hansenia guilliermondii were also implicated. L. plantarum were reported to be commonly isolated LAB species during cassava fermentation for gari production (Adesulu-Dahunsi, Sanni, Jeyaram, et al., 2017; Kostinek et al., 2005). Microorganisms that are responsible for masa fermentation are $L$. plantarum, L. fermentum sp., Pediococcus sp. and S. cerevisiae (Oyeyiola, 1990; Sanni \& Adesulu, 2013). Oranusi and Dahunsi (2015) also isolated genera Aspergillus, Rhizopus, Penicillium, Fusarium, Cephalosporium, Alternaria, Bacillus, Klebsiella, Staphylococcus, Lactobacillus, Pseudomonas, Proteus and Enterobacter during fermentation of maize for production of kokoro snack.

To ensure consistency in the food quality, well characterized autochthonous LAB and yeast isolates of food origin can be employed as starter cultures during controlled fermentation. Table 1 show the LAB and yeasts species that are involved in the fermentation of many $\mathrm{Ni}$ gerian IFFs.

The specific roles played by LAB and yeasts during fermentation may lead to the development of novel food and beverages that is developed through simple fermentation technology, which may also directly affect the functional and sensory properties of the food end products. During food fermentation, LAB and yeast strains have being reported to contribute to food functionality (Jespersen, 2003; Ogunremi, Agrawal, \& Sanni, 2015). Ogunremi et al. (2015) developed cereal-based functional food from cereals (the cereal mix contained; pearl millet, sorghum, and wheat grains) by fermenting the mix with probiotic strain Pichia kudriavzevii OG32. Increase in the developing and characterizing probiotics (mainly LAB and yeast species) will enhances it possibilities for health claim/uses and will be useful in starter culture selection and also for the production of nutraceuticals which create functional foods with increased bioavailability of nutrients 


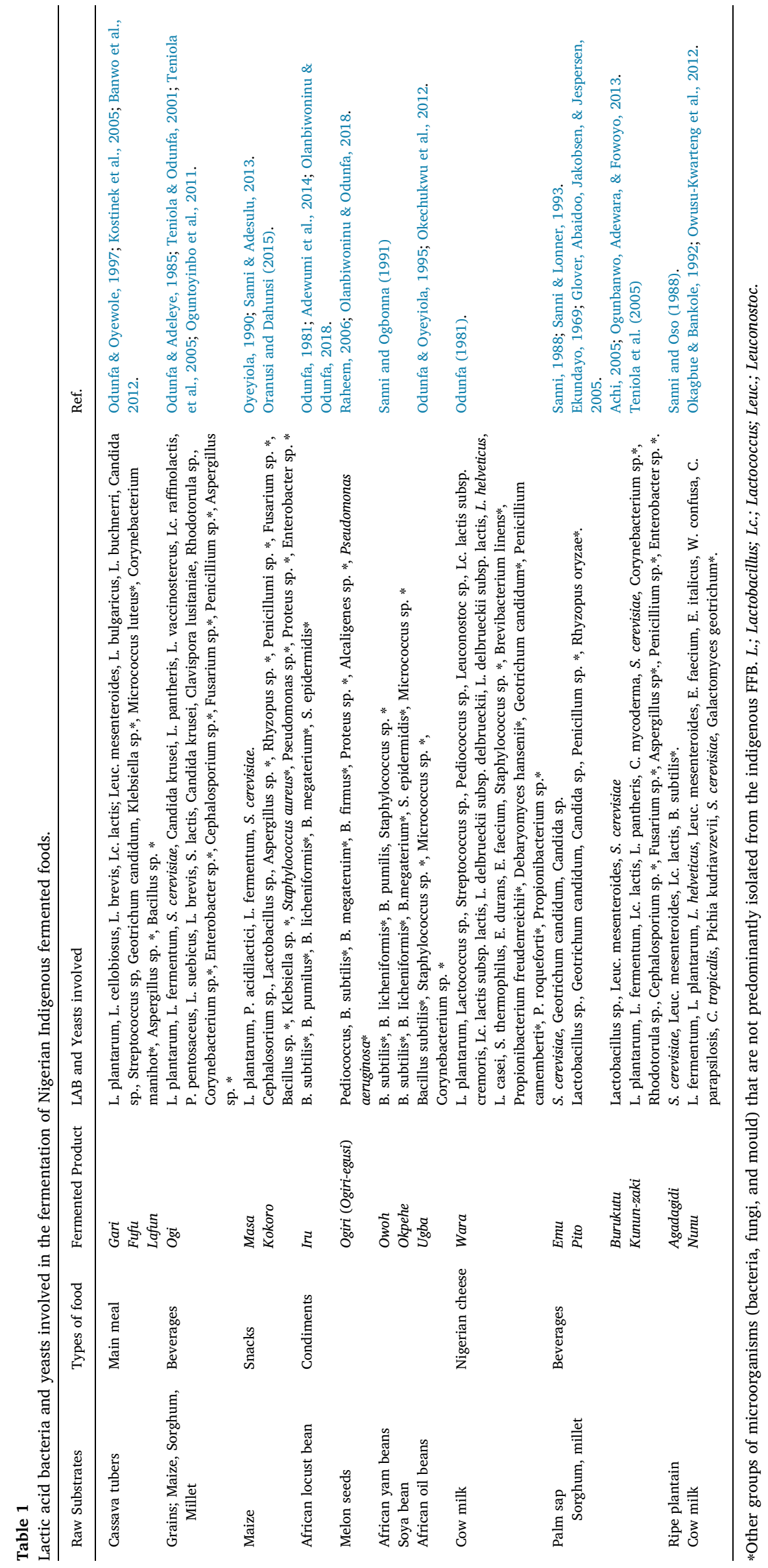




\section{LAB-yeast synergistic interactions in fermenting food matrix}

\section{Roles of LAB in traditional foods and beverages fermentation}

Fermentation of traditional foods and beverages is mainly carried out by LAB. Many researchers have reported that LAB are commonly isolated during fermentation of these IFF (Abdelgadir, Ahmed, \& Dirar, 1998; Adesulu-Dahunsi, Sanni, \& Jeyaram, 2017; Girum, Eden, \& Mogessie, 2005; Oguntoyinbo \& Narbad, 2015; Sanni \& Adesulu, 2013). During lactic acid fermentation, LAB and their enzymes produced are used to convert fermentable sugars in the food substrate into primarily lactic acid. Because of their long and safe historical use in production of FFB, occurrence in foods coupled with their promoting positive health impacts, LAB are 'Generally Recognized As Safe' (GRAS) status for human consumption (Adesulu-Dahunsi, Sanni, \& Jeyaram, 2017; Leroy \& De Vuyst, 2004). They can utilize substrates, produce metabolites and also possess probiotic potentials. LAB causes rapid acidification of the substrates by producing organic acids and technologically important substances, such as ethanol, aroma compounds, bacteriocins, exopolysaccharides (Adesulu-Dahunsi, Sanni, \& Jeyaram, 2018c; AdesuluDahunsi et al., 2018a, b, c, d; Adesulu-Dahunsi, Jeyaram, et al., 2018b), and thus enhances the food shelf-life and microbial safety. The roles played by $\mathrm{LAB}$ includes extending the shelf life and nutritional quality of FFB, treatment of acute infantile diarrhea, and their antimicrobial properties have been reported (Ogunbanwo, Sanni, \& Onilude, 2003; Oguntoyinbo \& Narbad, 2015).

Lactic acid fermentation enhances the shelf life of the fermented products, as they produce different antimicrobial metabolites during the fermentation process (Halm, Lillie, Sorensen, \& Jakobsen, 1993). The metabolites such as organic acids produced initiate an acidic environment which makes it unfavorable for the growth of undesirable and pathogenic microorganisms (Nout, 2009). LAB can also produce other antimicrobial bioactive molecules, such as ethanol, hydrogen peroxide, diacetyl, and bacteriocins (Ananou, Maqueda, MartinezBueno, \& Valdivia, 2007; Caplice \& Fitzgerald, 1999). Lactic acid fermentation are used as a means of decreasing the antinutrients content (i.e phytate and tannins) in the FFB and thus improves the bioavailability of essential dietary minerals in food products (O'sullivan et al., 2010).

\section{Roles of yeast in traditional foods and beverages fermentation}

Yeasts in a mixed population with LAB have major impact on the quality, taste, texture, and flavor of the fermented food products. They are important functional microorganisms present in many indigenous FFB, they are employed in production of baker's yeast for leavening of bread, they are also involved during wine and beer fermentation. $S$. cerevisiae was among the first microorganisms to be designated 'GRAS' status, and the first genetically modified organism used for recombinant production of food and feed additives (Jespersen, 2003). Yeasts play very important roles during fermentation of traditional foods and beverages across Africa and the world at large.

The predominant yeast species associated with African IFF is $S$. cerevisiae (Jespersen, 2003), though few researchers have also isolated Schizosaccharomyces pombe, S. japonicus, Candida castellii, C. fructus, C. intermedia, C. krusei, C. tropicalis, Geotrichum candidum, Hansenula anomala, Kloeckera apiculata, Pichia membraefaciens, P. ohmeri, Saccharomyces chevalieri, S. uvarum, Kluyveromyces africanus, Torulaspora delbrueckii and Rhodutorula grainis (De Vuyst et al., 2016; Jespersen, 2003). Applications of yeasts includes; ethanol production, single cell protein (SCP), feeds, industrial enzymes, and metabolites. Many yeast strains possess functional properties which results in enhanced nutritional values. The main role played by yeast during fermentation of foods and beverages is the fermentation of carbohydrates which results in formation of alcohols and other aroma compounds (Janssens, De Pooter, Schamp, \& Vandamme, 1992; Oh \& In, 2009).
Many traditional FFB in Africa are produced by fermentation involving LAB or yeasts and/or mixtures of both. During food fermentation, microbial behavior of the yeasts and LAB can result in the production of health-improving metabolites. Lactic acid fermentation plays important and predominant roles in the production of these fermented foods. Many LAB and yeasts have been isolated during fermentation of cereal and non-cereal products and have greatly influenced the organoleptic and the final quality of the food produced.

The LAB found in food performs unique role in the conversion of the substrates (raw materials) into lacto-fermented foods. These LAB work together and pair up with beneficial yeasts (and other beneficial microorganisms if present in the fermenting food matrix). Nigerian IFFs are produced majorly by spontaneous fermentation and $S$. cerevisiae frequently co-exists with LAB thereby microbiological succession usually takes place in the food matrices. The presence of LAB and yeast in the fermenting matrix contributes to the product characteristics. The process involved during natural or controlled food fermentation is as a result of complex microbial interactions which may be symbiotic or synergistic. The microorganisms do not interact only with the fermentable substrate but also with each other which cause division of labor between the microbes (Aidoo, Nout, \& Sarkar, 2006; Ayad, Verheul, Engels, Wouters, \& Smit, 2001). They also exchange metabolites and molecular signals thereby each individual cell in the mixture responds to the presence of others in the fermenting food matrix (Smid \& Hugenholtz, 2010). The microbial interaction and the successions of microorganisms involved during the fermentation process are associated with changes in the environmental conditions and raw material compositions (Keller \& Surette, 2006).

Various researchers have reported the co-existence and synergistic association between LAB and yeasts in African traditional fermented products (Omemu, 2011; Smid \& Hugenholtz, 2010). Traditional cerealbased fermentations are performed by synergistic interaction between $\mathrm{LAB}$ and yeast. Researchers have reported that the growth of yeast in fermented foods is favored by acidifying environment created by LAB. The growth of LAB is also stimulated by the presence of yeast, which can provide growth factors, such as vitamins and soluble nitrogen compounds. The major metabolic activities of these microorganisms during the fermentation of cereal based foods are acidification, flavor formation, and leavening. The co-existence and association between yeast species (S. cerevisiae, R. graminis, C. tropicalis, G. candidum $C$. krusei) and LAB (L. fermentum, L. plantarum, L. brevis) have been reported during fermentation dynamic of cereal for ogi production, with $L$. plantarum and $L$. fermentum being the dominant LAB species and $S$. cerevisiae as the dominant yeast species (Teniola, Odunfa, \& Holzapfel, 2005).

Production of alcohol and aroma compounds by yeast gives a typical flavor to fermented products and also impact on the food quality and their nutritional value (Jespersen, Halm, Kpodo, \& Jacobsen, 1994; Torner, Martinez-Anaya, Antuna, \& Benedito de Barber, 1992). Some yeast species have been reported to possess amylolytic, protease and phytase activities, these functions contributes to breaking down fermenting dough and allow better access to the essential minerals present in the substrates (Okechukwu et al., 2012; Omemu, 2011). Omemu, Oyewole, and Bankole (2007) reported that yeasts isolated during fermentation of maize for the production of ogi secretes extracellular enzymes and also possess amylolytic activities which aids the breakdown of carbohydrates in food to simple sugars for the use of LAB. Olanbiwoninu and Odunfa (2018) studied the interactions between bacteria and yeasts during the fermentation of iru and ogiri condiments, and reported that the microorganisms involved formed a complex consortium. The behavior of the microorganisms based on the production of acids and metabolites which have effect on the proteolytic bacteria indicated either symbiotic or synergistic effects.

The significant decrease in $\mathrm{pH}$ and simultaneous increase in acidity 
observed during spontaneous fermentation of cereal grains for production of ogi and kunun-zaki when compared with the ones fermented with only LAB or yeast culture was attributed to the combined action of yeast and LAB (Nwachukwu et al., 2010). Lactobacilli are the most important organisms that produced acidity in maize fermentation (Sanni \& Adesulu, 2013). These organisms have also been implicated as partly responsible for initiating acidification in fermenting maize dough (Halm et al., 1993).

$S$. rouxii and $S$. cerevisiae have been implicated as being partly responsible for the organoleptic properties of fermented maize (Annan, Poll, Sefa-Dedeh, Plahar, \& Jakobsen, 2003). S. cerevisiae has also been reported to excite the growth of $\mathrm{LAB}$, by providing essential metabolites such as pyruvate, amino acids and vitamins and they also utilized certain metabolites produced by LAB as their carbon sources (Akinrele, 1970; Gadaga, Mutukumira, \& Narvhus, 2001). Several yeast species have been reported to have pectinase activity that could be of importance to other microorganisms during fermentation. Yeasts can influence the antioxidant capacity of fermented food products through increase in the phenolic contents (Wang, Wu, \& Shyu, 2014). Research studies have shown that cereal fermentation leads to phytase-dependent dephosphorylation of phytic acid. The phytic acid chelates several nutritionally important minerals in food, thus its degradation result in accessibility of essential minerals (i.e iron, zinc, calcium, and magnesium). The phytase activity present in the cereals is activated during LAB acidification, thereby leading to desirable biochemical changes such as production of aromatic compounds, proteolytic and lipolytic activities (Lioger, Leenhardt, Demigne, \& Remesy, 2007; MoslehiJenabian, Lindegaard, \& Jespersen, 2010; Reale et al., 2004).

$\mathrm{LAB}$ and yeasts have also been implicated during the fermentation of many other non-cereal products like fermented cassava tubers (Amoa-Awua et al., 1996). Lactobacillus sp. and L. mesenteroides were initially isolated during fermentation of cassava tubers to produce fufu and gari, as the acidity of the fermenting tubers changes, they allow the $S$. cerevisiae to take it turn. The synergistic metabolic activities between $\mathrm{LAB}$ and yeast involved in certain food fermentation influence the nutritional and functional properties of foods. This has enabled the selection of strains with desirable properties for use as starter culture in production of functional fermented foods. During food fermentation, the result of fermentative activities and interaction between LAB and yeast gives the food end product desirable characteristics and has positively affect the nutritional quality, sensory attributes and shelf life of fermented foods. The isolated LAB species have been used, often in combination with yeast species, as starter cultures in controlled fermentation. In indigenous food fermentation processes, the complex activities performed by the microbial consortia could only be achieved because of the synergistic interaction between these organisms. Lactic acid production, rapid acidification, extended product shelf life, improved organoleptic characteristics amongst other functional, technological and probiotic properties can therefore be achieved with the combination of well characterized LAB and yeast species.

\section{Safety considerations in traditional fermentation of foods and beverages}

Fermented foods are valued by many cultures for their safety potentials and health benefits. These foods are produced at a $\mathrm{pH}$ level of 4.0 or lower, an indication that they are safe for human consumption. Fermented foods are generally considered safe because the lactic acid produced by $\mathrm{LAB}$ during the fermentation process inhibits the activities of spoilage bacteria and destroy any potential pathogens that may be present in the food, also the involvements and activities of LAB and yeasts during food fermentation or processing enables the conversion of perishable foods in their raw state to safe, edible and shelf-stable form, thus aids in food digestibility and production of more nutritious and palatable food that are of enormous importance to human health. Cases of food poisoning or foodborne infection rarely occur in traditional foods that are properly fermented. Though, menace of food spoilage and food borne diseases arising from improper production of foods are prevalent in many developing countries of Africa (Achi, 2005; Oyewole, 1997).

Food safety concern as per microbial contamination is a subject of paramount importance. However, some basic food safety practices must be ensured before, during and after food fermentation, these includes, hand washing, proper cleaning of food contact surfaces, containers, storage time which may affects the food texture. It is also important to understand the roles that each processing stages i.e. peeling, washing, grinding, dehydration, packaging, and fermentation play in the safety of the final product because fermentation cannot eliminate all foodrelated health risks, therefore this method of food preservation should not replace the practice of food hygiene principles. It should also be taken to consideration that during traditional household food fermentation process, adequate time must be ensured by mothers and the food processors for production of wholesome foods and beverages, care should be taken that no unjustified shortcuts are allowed, because lack of adequate fermentation time may have significant implications as regarding the food safety and nutritional quality of fermented foods, and may also limit the effectiveness of acidification by LAB.

Other food safety consideration that may arise from handling and processing of foods in order to avoid hazards and growth of pathogenic microbes should be safeguarded. Improvement of product safety can be achieved by application of Hazard Analysis Critical Control Point (HACCP) from the raw material stage to processing and consumption by adhering strictly to the principles of Good Manufacturing Practice (GMP) and Good Hygiene Practice (GHP) (WHO, 1995), which includes; identifying points where hazards might occur during food production and fermentation process and employing accurate preventive measures to avert these hazards from occurring. For example, in cassava processing, the tuber must be cut into smaller sizes so as to enable enzymatic degradation of toxic substance and residue present (cyanogenic glycosides). Another is the elimination of mouldy growth in raw cereal grains to avoid possible mycotoxin contamination and use of clean and safe water. Other possible ways of minimizing the risk associated with traditional FFB preparation and accelerating spontaneous fermentation processes may include acceleration of the fermentation process by back slopping or implementation of carefully selected multifunctional strains as starter or adjunct culture under hygienic conditions, development and use of well characterized probiotics strains exhibiting health-promoting properties for controlled food fermentation and production of functional foods (Ogunremi et al., 2015). Quick responsiveness to food safety by the traditional producers, food handlers and consumers will help in strengthening and enforcement of food standards and improved hygienic practices during food production and processing, which may lead complete eradication of foodborne illnesses.

\section{Conclusion}

Fermentation as a method of food preservation technology is of economic importance to many developing countries in Africa because it is easily affordable. The microorganisms responsible for the fermentation process are indigenously present on the substrates as microflora, or they may be added as starter cultures. The investigation of various IFFs of Africa showed that the fermentation majorly involved the activities of LAB and yeasts. Thus, the study of microbial interaction and the fermentation dynamics will help in optimizing the application and the performances of the microorganisms for improved food products, also adequate selection of LAB and yeast strains with suitable technological properties will lead to the development of appropriate starter cultures. Controlled fermentation can be encouraged for upgrading of the product quality and consistence. 


\section{Declaration of competing interest}

Authors declare no conflict of interest whatsoever in this paper. All of us read and approved this submission.

\section{Acknowledgment}

This research received funding from the Ton Duc Thang University,

\section{Ho Chi Minh City, Vietnam}

\section{References}

Abdelgadir, W. S., Ahmed, T. K., \& Dirar, H. A. (1998). The traditional fermented milk products of the Sudan. International Journal of Food Microbiology, 44, 1-13.

Achi, O. K. (2005). The potential for upgrading traditional fermented foods through biotechnology. African Journal of Biotechnology, 4, 375-380.

Adesulu-Dahunsi, A. T., Jeyaram, K., \& Sanni, A. I. (2018a). Probiotic and technological properties of exopolysaccharide producing Lactic acid bacteria isolated from some cereal-based Nigerian indigenous fermented food products. Food Control, 92 225-231.

Adesulu-Dahunsi, A. T., Jeyaram, K., Sanni, A. I., \& Banwo, K. (2018b). Production of exopolysaccharide by strains of Lactobacillus plantarum YO175 and OF101 isolated from traditional fermented cereal beverage. PeerJ, 6, 1-21.

Adesulu-Dahunsi, A. T., Sanni, A. I., \& Jeyaram, K. (2017). Rapid differentiation among Lactobacillus, Pediococcus and Weissella species from some Nigerian indigenous fermented foods. LWT- Food Science and Technology, 77, 39-44.

Adesulu-Dahunsi, A. T., Sanni, A. I., \& Jeyaram, K. (2018c). Production, characterization and In vitro antioxidant activities of exopolysaccharide from Weissella cibaria GA44. LWT Food Science and Technology, 87, 432-442.

Adesulu-Dahunsi, A. T., Sanni, A. I., Jeyaram, K., \& Banwo, K. (2017). Genetic diversity of Lactobacillus plantarum strains from some indigenous fermented foods in Nigeria. LWT Food Science and Technology, 82, 199-206.

Adesulu-Dahunsi, A. T., Sanni, A. I., Jeyaram, K., Ojediran, J. O., Ogunsakin, A. O., \& Banwo (2018d). Extracellular polysaccharide from Weissella confusa OF126: Production, optimization, and characterization. International Journal of Biological Macromolecules, 111, 514-525.

Adesulu, A. T., \& Awojobi, K. O. (2014). Enhancing sustainable development through indigenous fermented food products in Nigeria. African Journal of Microbiology Research, 8, 1338-1343.

Adewumi, G. A., Oguntoyinbo, F. A., Romi, W., Singh, T. A., \& Jeyaram, K. (2014). Genome subtyping of autochthonous Bacillus species isolated from iru, a fermented Parkia biglobosa seed. Food Biotechnology, 28, 250-268.

Aidoo, K., Nout, M., \& Sarkar, P. (2006). Occurrence and function of yeasts in Asian indigenous fermented foods. FEMS Yeast Research, 6, 30-39.

Akinrele, I. A. (1970). Fermentation studies on maize during the preparation of a traditional African starch cake food. Journal of the Science of Food and Agriculture, 21, 619-625.

Amoa-Awua, W. K. A., Appoh, F. E., \& Jakobsen, M. (1996). Lactic acid fermentation of cassava dough into agbelima. International Journal of Food Microbiology, 31, 87-98.

Ananou, S., Maqueda, M., Martinez-Bueno, M., \& Valdivia, E. (2007). Biopreservation, an ecological approach to improve the safety and shelf-life of foods. In A. Mendez-Vilas (Ed.). Communicating current research and education topics and trends in applied microbiology. Madrid: FORMATEX.

Annan, N., Poll, L., Sefa-Dedeh, S., Plahar, W., \& Jakobsen, M. (2003). Volatile compounds produced by Lactobacillus fermentum, Saccharomyces cerevisiae and Candida krusei in single starter culture fermentations of Ghanaian maize dough. Journal of Applied Microbiology, 94, 462-474.

Ayad, E. H., Verheul, A., Engels, W. J., Wouters, J. T., \& Smit, G. (2001). Enhanced flavor formation by combination of selected lactococci from industrial and artisanal origin with focus on completion of a metabolic pathway. Journal of Applied Microbiology, 90, 59-67.

Banwo, K., Sanni, A. I., Tan, H., \& Tian, Y. (2012). Phenotypic and genotypic characterization of lactic acid bacteria isolated from some Nigerian traditional fermented foods. Food Biotechnology, 26, 124-142.

Caplice, E., \& Fitzgerald, G. F. (1999). Food fermentations: Role of microorganisms in food production and preservation. International Journal Of Food Microbiology, 50, 131-149.

De Vuyst, L., Harth, H., Van Kerrebroeck, S., \& Leroy, F. (2016). Yeast diversity of sourdoughs and associated metabolic properties and functionalities. International Journal of Food Microbiology, 239, 26-34.

Ekundayo, J. A. (1969). The production of pito, a Nigerian fermented beverage. Journal of Food Technology, 4, 217-225.

Franz, C. M., Julius, M., Abriouel, H., Benomar, N., Reid, G., Galvez, A., et al. (2014) African fermented foods and probiotics. International Journal of Food Microbiology, 190, 84-96.

Gadaga, T. H., Mutukumira, A. N., \& Narvhus, J. A. (2001). The growth and interaction of yeasts and lactic acid bacteria isolated from Zimbabwean naturally fermented milk in UHT milk. International Journal of Food Microbiology, 68, 21-32.

Girum, T., Eden, E., \& Mogessie, A. (2005). Assessment of the antimicrobial activity of lactic acid bacteria isolated from Borde and Shameta, traditional Ethiopian fermented beverages, on some foodborne pathogens and effect of growth medium on inhibitory activity. International Journal of Food Safety, 5, 13-20.
Glover, R. L., Abaidoo, R. C., Jakobsen, M., \& Jespersen, L. (2005). Biodiversity of Saccharomyces cerevisiae isolated from a survey of pito production sites in various parts of Ghana. Systematic \& Applied Microbiology, 28, 755-761.

Halm, M., Lillie, A., Sorensen, A. K., \& Jakobsen, M. (1993). Microbiology and aromatic characteristics of fermented maize doughs for Kenkey production in Ghana. International Journal of Food Microbiology, 19, 135-143.

Hussain, M. A. (2018). Molecular techniques for the identification of LAB in fermented cereal and meat products. Molecular techniques in food biology: Safety, biotechnology, authenticity and traceability. Willey.

Janssens, L., De Pooter, H. L., Schamp, N. M., \& Vandamme, E. J. (1992). Review: Production of flavours by microorganisms. Process Biochemistry, 27, 195-215.

Jespersen, L. (2003). Occurrence and taxonomic characteristics of strains of Saccharomyces cerevisiae predominant in African indigenous fermented foods and beverages. FEMS Yeast Research, 3, 191-200.

Jespersen, L., Halm, M., Kpodo, K., \& Jacobsen, M. (1994). Significance of yeasts and moulds occurring in maize dough fermentation for kenkey production. International Journal of Food Microbiology, 24, 239-248.

Keller, L., \& Surette, M. G. (2006). Communication in bacteria: An ecological and evolutionary perspective. Nature Reviews Microbiology, 4, 249-258.

Kostinek, M., Specht, I., Edward, V., Schillinger, U., Hertel, C., \& Holzapfel, W. (2005). Diversity and technological properties of predominant lactic acid bacteria from fermented cassava used for the preparation of Gari, a traditional African food. Systematic \& Applied Microbiology, 28, 527-540.

Leroy, F., \& De Vuyst, L. (2004). Lactic acid bacteria as functional starter cultures for the food fermentation industry. Trends in Food Science \& Technology, 15, 67-78.

Lioger, D., Leenhardt, F., Demigne, C., \& Remesy, C. (2007). Sourdough fermentation of wheat fractions rich in fibres before their use in processed food. Journal of the Science of Food and Agriculture, 87, 1368-1373.

Moslehi-Jenabian, S., Lindegaard, P., \& Jespersen, L. (2010). Beneficial effects of probiotic and food borne yeasts on human health. Nutrition, 2, 449-473.

Nout, M. J. R. (2009). Rich nutrition from the poorest - cereal fermentations in Africa and Asian. Food Microbiology, 26, 685-692.

Nwachukwu, E., Achi, O. K., \& Ijeoma, I. O. (2010). Lactic acid bacteria in fermentation of cereals for the production of indigenous Nigerian foods. African Journal of Food Science and Technology, 1, 021-026.

Odunfa, S. A. (1981). Microorganisms associated with fermentation of African locust bean during iru preparation. Journal of Plant Foods, 25, 249-250.

Odunfa, S. A., \& Adeleye, S. (1985). Microbiological changes during the traditional production of Ogi baba, a West African fermented sorghum gruel. Journal of Cereal Science, 3, 173-180.

Odunfa, S. A., \& Oyewole, O. B. (1997). African fermented foods. (2nd eds). Microbiology of fermented foods: Vol. 2, (pp. 713-752). London: Blackie Academic and Professional 1997.

Odunfa, S. A., \& Oyeyiola, O. E. (1985). Microbiological study of the fermentation of Ugba a Nigerian indigenous fermented food. Journal of Plant Foods, 6, 155-163.

Ogunbanwo, S. T., Adewara, A. O., \& Fowoyo, P. T. (2013). Effect of fermentation by pure cultures of Lactobacillus fermentum 1 and Saccharomyces cerevisiae as starter cultures in the production of burukutu. New York Science Journal, 6, 73-81.

Ogunbanwo, S. T., Sanni, A. I., \& Onilude, A. A. (2003). Characterization of bacteriocin produced by Lactobacillus plantarum F1 and Lactobacillus brevis OG1. African Journal of Biotechnology, 2, 219-227.

Ogunremi, O. R., Agrawal, R., \& Sanni, A. I. (2015). Development of cereal- based functional food using cereal- mix substrate fermented with probiotic strain - Pichia kudriavzevii OG 32. Food Sciences and Nutrition, 3, 1-9.

Ogunsakin, A. O., Vanajakshi, V., Anu-Appaiah, K. A., Vijayendra, S. V. N., Walde, S. G., Banwo, K., et al. (2017). Evaluation of functionally important lactic acid bacteria and yeasts from Nigerian sorghum as starter cultures for gluten-free sourdough preparation. Lebensmittel-Wissenschaft und -Technologie- Food Science and Technology, 82, 326-334.

Oguntoyinbo, F. A., \& Narbad, A. (2015). Multifunctional properties of Lactobacillus plantarum strains isolated from fermented cereal foods. Journal of Functional Foods, 17, 621-631.

Oguntoyinbo, F. A., Tourlomousis, P., Gasson, M. J., \& Narbad, A. (2011). Analysis of bacterial communities of traditional fermented West African cereal foods using culture independent methods. International Journal of Food Microbiology, 145, 205-210.

Oh, N., \& In, M. (2009). Phytate degradation by Leuconostoc mesenteroides KC51 cultivation in soymilk. African Journal of Biotechnology, 8, 3023-3026.

Okagbue, R. N., \& Bankole, N. O. (1992). Use of starter cultures containing Streptococcus diacetylactis, Lactobacillus brevis and Saccharomyces cerevisiae for fermenting milk for production of Nigerian nono. World Journal of Microbiology and Biotechnology, 8, 251-253.

Okechukwu, R. I., Ewelike, N., Ukaoma, A. A., Emejulu, A., \& Azuwike, C. O. (2012). Changes in the nutrient composition of the African oil bean meal "ugba" (Pentaclethre macrophylla Benth) subjected to solid state natural fermentation. Journal of Applied Bioscience, 51, 3591-3595.

Olanbiwoninu, A. A., \& Odunfa, S. A. (2018). Microbial interaction in selected fermented vegetable condiments in Nigeria. International Food Research Journal, 25, 439-455.

Omemu, A. M. (2011). Fermentation dynamics during production of ogi, a Nigerian fermented cereal porridge. Report and Opinion, 3, 8-17.

Omemu, A. M., Oyewole, O. B., \& Bankole, M. O. (2007). Significance of yeasts in the fermentation of maize for ogi production. Food Microbiology, 24, 571-576.

Oranusi, S., \& Dahunsi, S. O. (2015). Preliminary study on hazards and critical control points of kokoro, a Nigerian indigenous fermented maize snack. SpringerPlus, 4, 253.

Owusu-Kwarteng, J., Akabanda, F., Nielsen, D. S., Tano-Debrah, K., Glover, R. L. K., \& Jespersen, L. (2012). Identification of lactic acid bacteria isolated during traditional fura processing in Ghana. Food Microbiology, 32, 72-78. 
Oyewole, O. B. (1997). Lactic fermented foods in Africa and their benefits. Food Control, 8, 289-297.

Oyeyiola, G. P. (1990). Microbiological and biochemical changes during the fermentation of maize grains for masa production. World Journal of Microbiology and Biotechnology, 6, 171-177.

O'sullivan, L., Murphy, B., Mcloughlin, P., Duggan, P., Lawlor, P. G., \& Hughes, H. (2010). Prebiotics from marine macroalgae for human and animal health applications. Marine Drugs, 8, 2038-2064.

Padonou, S. W., Nielsen, D. S., Hounhouigan, J. D., Thorsen, L., Nago, M. C., \& Jakobsen, M. (2009). The microbiota of Lafun, an African traditional cassava food product. International Journal of Food Microbiology, 133, 22-30.

Raheem, B. (2006). Developments and microbiological applications in african foods: Emphasis on Nigerian wara cheesePh.D. Thesis. University of Helsinki Finland). .

Reale, A., Mannina, L., Tremonte, P., Sobolev, A. P., Succi, M., Sorrentino, E., et al. (2004). Phytase degradation by lactic acid bacteria and yeast during the whole meal dough fermentation: A 31P NMR study. Journal of Agricultural and Food Chemistry, 52, 6300-6305.

Sanni, A. I. (1988). Chemical studies on sekete beer. Food Chemistry, 33, 187-191.

Sanni, A. I. (1993). The need for process optimization of African fermented foods and beverages. International Journal of Food Microbiology, 18, 85-95.

Sanni, A. I., \& Adesulu, A. T. (2013). Microbiological and physico-chemical changes during fermentation of maize for masa production. African Journal of Microbiology Research, 7, 4355-4362.

Sanni, A. I., \& Lonner, C. (1993). Identification of yeasts isolated from Nigerian traditional alcoholic beverages. Food Microbiology, 10, 517-523.

Sanni, A. I., \& Ogbonna, D. N. (1991). The production of owoh- a Nigerian fermented seasoning agent from cotton seed (Gossypium hirsutum L.). Food Microbiology, 8, 223-229.

Sanni, A. I., \& Oso, B. A. (1988). The production of agadagidi- a Nigerian fermented beverage. Food Nahrung, 32, 319-326.

Sieuwerts, S., de Bok, F. A., Hugenholtz, J., \& van Hylckama Vlieg, J. E. (2008).

Unraveling microbial interactions in food fermentations: From classical to genomics approaches. Applied and Environmental Microbiology, 74, 4997-5007.

Smid, E. J., \& Hugenholtz, J. (2010). Functional genomics for food fermentation process Annual Review in Food Science and Technology, 1, 497-519.

Teniola, O. D., \& Odunfa, S. A. (2001). The effects of processing methods on the level of lysine, methionine and the general acceptability of ogi processed using starter cultures. International Journal of Food Microbiology, 63, 1-9.

Teniola, O. D., Odunfa, S. A., \& Holzapfel, W. H. (2005). Selection, use and the influence of starter cultures in the nutrition and processing improvement of ogi. In I. D. Brouwer, A. S. Traoré, \& S. Trèche (Eds.). Proceedings of the $2^{\text {nd }}$ international workshop: Food-based approaches for a healthy nutrition. Burkina faso (pp. 697-708). Presses Universitaires deOuagadougou 2005.

Toma, M. M., \& Pokrotnieks, J. (2006). Probiotics as functional food: Microbiological and medical aspects. Acta Universitatis Latviencis, 710, 117-129.

Torner, M. J., Martinez-Anaya, M. A., Antuna, B., \& Benedito de Barber, C. (1992). Headspace flavour compounds produced by yeasts and lactobacilli during fermentation of pre ferments and bread doughs. International Journal of Food Microbiology, $15,145-152$.

Vieira-Dalodé, G., Jespersen, L., Hounhouigan, J., Moller, P. L., Nago, C. M., \& Jakobsen, M. (2006). Lactic acid bacteria and yeasts associated with gowé production from sorghum in Benin. Journal of Applied Microbiology, 103, 342-349.

Wang, C. Y., Wu, S. J., \& Shyu, Y. T. (2014). Antioxidant properties of certain cereals a affected by food-grade bacteria fermentation. Journal of Bioscience and Bioengineering, $117,449-456$.

WHO (1995). Bridging the gaps. The world health reportsGeneva: World Health Organization. 